\title{
Learning Styles: Psychology Shouldn't Condone Mythology
}

\author{
David T Morse*
}

Department of Counseling and Educational Psychology, Mississippi State University, Oktibbeha , Mississippi, United States

Received: February 18, 2014; Accepted: February 19, 2014; Published: February 20, 2014

*Corresponding author: David T Morse, Department of Counseling and Educational Psychology, Mississippi State University, Mississippi, United States, Tel: 662 325-0969; Fax: 662-325-0975; E-mail: DMorse@colled.msstate.edu

\section{Editorial}

Among popular myths and legends in the community of educators and learners is that of learning styles. As evidence of the topic's popularity, a PsychINFO search for "learning style" yields almost 12,000 hits. Add to that the electronic data bases MEDLINE, SocINDEX, Academic Search Complete, Academic Search Premier, Health Source: Nursing/Academic Edition, EconLit, and Humanities International Complete, and nearly 49,000 hits are found. The Buros Institute's Mental Measurements Yearbook has published reviews on no fewer than 20 different measures of learning style. A Google ${ }^{\mathrm{TM}}$ search yields well over a half a billion hits. The premise of learning styles is seductively simple: Identify the dominant style of the learner, and instructional conditions can be matched to that style to optimize learning. It is a belief all but completely unsupported by empirical evidence [1-4]. Even initial reports [5] of a promising example (G. L. Anderson's 1941 dissertation study) turned out later, upon reanalysis, not to hold up [6]. Others [4] turned out to be missing key information, or only show effects some, and not all of the time. Given this, why is the belief in learning styles so pervasive? There are at least three reasons.

First, the popular mythology is easily and uncritically embraced. Riener and Willingham [3] reported that, among their undergraduates taking psychology courses, typically over $90 \%$ endorse statements like "people have their own learning styles" (p. 35). Just as people enjoy different hobbies, some may enjoy working together more so than working alone, or may enjoy working with their hands more than reading books. From this very common reality, it takes little for individuals to make the inferential leap that there must, therefore, be a learning condition that's best for them. Furthermore, most people don't think of the numerous counterexamples that occur in everyday life. How many "visual learner" children successfully-and to their parents' consternation-memorize and sing aloud commercial advertisement jingles that are only heard?

Second, most of the literature simply fails to address the question [2,3]. There is ample evidence that: (a) people differ in their expressed learning style preferences; (b) a number of learners express higher comfort or satisfaction in certain environments than others; (c) there are individual differences in learners that do result in differential learning outcomes; and (d) some instructional conditions are superior to others for learning specific skills. However, relatively few of the published studies meet the standards that [7] Cronbach and Snow (1977) or [2] Pashler outline: (a) Determine learners' styles; (b) Create at least two instructional conditions that differ demonstrably with respect to style emphasis; (c) Randomly assign learners to conditions that do or don't match their styles; and (d) Compare outcomes on common measures of attainment, looking for disordinal ("crossover") interactions such that students of style $\mathrm{X}$ fare better in learning condition $\mathrm{X}$ than $\mathrm{Y}$, whereas learners of style $Y$ fare better in learning condition $Y$ than $X$.

Third, there is truth to related beliefs, one of which is the belief that learning conditions need to take into account characteristics of the learner [8]. However, these refer to abilities and possession of prerequisite skills, not style. A second related belief is that, were one to deny that learning styles exist, the conclusion must be that everyone is the same, which we know to be false [3].

Where does this take us, and how does it apply to SOJ Psychology? First, one of the key attributes about psychology as a discipline is the reliance on having a scientific basis. So vital is this belief among researchers and practitioners that the American Psychological Society changed its name in 2006 to the Association for Psychological Science. Scientifically, there is a glaring lack of evidence to support belief in the utility of learning styles. Second, we should all make it a priority to discourage practitioners from embracing the siren call of learning styles as a meaningful construct for the design or delivery of instruction; there are too many other pressing needs and too many sound, evidence-based practices from which to draw. Finally, for SOJ Psychology, we would strongly encourage researchers to spend their valuable time looking in more promising places than in learning styles.

\section{References}

1. Mayer RF (2011) Does styles research have useful implications for educational practice? Learning and Individual Differences 21(3): 319-320.

2. Pashler H, McDaniel M, Rohrer D, Bjork R (2008) Learning styles: Concepts and evidence. Psychological Science in the Public Interest 9(3): 105-119. 
3. Riener C, Willingham D (2010) The myth of learning styles. Change 42(5): 32-35

4. Rohrer D, Pashler H (2012) Learning styles: Where's the evidence? Medical Education 46(7): 630-635.

5. Cronbach LJ (1966) How can instruction be adapted to individual differences? In: R. M. Gagné (Ed.), Learning and individual differences. Columbus, OH: Merrill.
6. Cronbach LJ, Webb N (1975) Between-class and within-class effects in a reported aptitude $\mathrm{x}$ treatment interaction: Reanalysis of a study by G. L. Anderson. Journal of Educational Psychology 67(6): 717-724.

7. Cronbach LJ, Snow RE (1977) Aptitudes and instructional methods: Handbook for research of interactions. New York: Wiley.

8. Gagne RM, Wager WW, Golas K, Keller JM (2005) Principles of instructional design. $\left(5^{\text {th }}\right.$ edn), Cengage, Boston, MA. 